\title{
EFFECT OF SILICON ON PHYTOCHEMICAL AND MEDICINAL PROPERTIES OF ALOE VERA UNDER COLD STRESS
}

\author{
AZARFAM, S. P. ${ }^{1 *}$ - NADIAN, H. ${ }^{2}-$ MOEZZI, A. ${ }^{3}-$ GHOLAMI, A. ${ }^{1}$ \\ ${ }^{1}$ Department of Agriculture, Islamic Azad University, Ahvaz, Iran \\ (phone: +98-91-3326-7562; fax: +98-21-7751-7398) \\ ${ }^{2}$ University of Agricultural Sciences and Natural Resources of Ramin, Ahvaz, Iran \\ (phone: +98-91-6113-3710; fax: +98-21-7751-7398) \\ ${ }^{3}$ University of Shahid Chamran, Ahvaz, Iran \\ (phone: +98-91-6313-9813; fax: +98-21-7751-7398) \\ *Corresponding author \\ P.azarfam2018@gmail.com; phone+98-91-2135-0769; fax +98-21-7751-7398
}

(Received $11^{\text {th }}$ Aug 2018; accepted $2^{\text {nd }}$ Jan 2019)

\begin{abstract}
Plants use the enzymatic and non-enzymatic antioxidant defense mechanisms to avoid and/or tolerate environmental stresses. As a useful element in plants, silicon plays an important role in activating these defense systems and thus in improving plant resistance to environmental stresses. The present research studied the effect of silicon on important antioxidants including Super Oxide Dismutase (SOD) and Catalase (CAT) and also on glucomannan, mannose, and aloin in Aloe vera. 60 Aloe vera plant of Aloe barbadensis Mill variety were taken. After applying the fertilizer treatments during cold stress treatment, 30 pots were placed at $25^{\circ} \mathrm{C}$ (control) and 30 pots at $4{ }^{\circ} \mathrm{C}$ (stress), and then fertilizer sidetreatments were applied. During their growth, the plants were treated with various silicon concentrations $(500,1000,1500$, and $2000 \mathrm{mg} / \mathrm{l})$. Ninety days after they were planted, 30 of the plants were separated and exposed to cold stress at $4{ }^{\circ} \mathrm{C}$ for seven days. After applying the cold stress treatment, leaf samples were taken and analyzed simultaneously from treated and untreated plants. Results of ANOVA showed that cold stress and silicon treatments had significant effects on SOD, CAT, glucomannan, mannose, and aloin. Application of cold stress increased SOD and CAT activities and reduced glucomannan, mannose, and aloin concentrations. Increases in silicon concentration improved both enzymatic antioxidant activity and concentrations of soluble sugars and of aloin in Aloe vera. These results indicate that silicon plays a key role in enhancing plant defense systems against cold stress. Therefore, application of silicon fertilizers is of great importance in reducing losses caused by climatic stresses and in achieving the goals of sustainable agriculture.
\end{abstract}

Keywords: antioxidant, aloe vera, silicon, plant resistance, sustainable agriculture

\section{Introduction}

Among the various biotic stresses, cold stress or low temperature (LT) is one of the common important climatic factors that limit plant growth and yield (Adam and Murthy, 2014). It has been estimated that more than 15 percent of global agricultural products are lost annually due to frost damage (Zou et al., 2007). This type of stress also occurs repeatedly in Iran every year and inflicts heavy losses on farmers and orchard owners (Talebi, 2013). Considering the ever-growing human population and the purpose of developing sustainable agriculture and food security, enhancement of plant resistance to environmental stresses becomes important (Liang et al., 2015).

Plants continuously respond to changes in their surrounding environment and develop various efficient mechanisms to adapt themselves in the best possible way to various stresses in order to survive. Use of enzymatic and non-enzymatic antioxidant 
systems is among the important strategies that plants employ to avoid and/or tolerate environmental stresses (Jung, 2004). In recent years, many advances have been made in understanding the mechanisms and processes involved in defensive adaptation to abiotic stresses in various plant species (Adam and Murthy, 2014). When faced with stresses, reactive oxygen species $\left(\mathrm{ROS}_{\mathrm{s}}\right)$ such as superoxide anions $\left(\mathrm{O}^{2-}\right)$, hydroxyl radicals $(\mathrm{OH})$, and hydrogen peroxide $\left(\mathrm{H}_{2} \mathrm{O}_{2}\right)$ are excessively produced in plants. This increases cellular antioxidant potential that causes oxidative damages in plants (Ali and Alqurainy, 2006). Production of ROSs at times of stress is a natural metabolic process that happens in cells of all aerobic organisms (Alsher et al., 1997) and plays a very important role in activating the defensive system against biotic and abiotic stresses (Bafana et al., 2011). Due to the limitations in the quantities of $\mathrm{NADP}^{+}$, one of the sites where ROSs may form is in the electron transfer chain. Induction of ROSs starts the processes of Lipid Per Oxidation (LPO) and also degradation of protein, pigments, and other cellular compounds (Allen, 1995; Balakhnina et al., 2010; Halliwell, 1984). Therefore, plants have efficient antioxidant defense systems to detoxify these ROSs and reduce damages that they cause (Gill and Tuteja, 2010). These defense systems consist of molecular antioxidants and antioxidant enzymes that degrade ROSs (Larson,1988). The enzymatic antioxidant system includes several efficient enzymes such as SOD and CAT, guaiacol peroxidase, ascorbate peroxidase, and glutathione reductase (Asada, 2006; Gunes et al., 2007b). The first enzyme to detoxify these reactive oxygen species in plants is SOD that converts superoxide into $\mathrm{H}_{2} \mathrm{O}_{2}$ and $\mathrm{O}_{2}$ and protects cells against the oxidative stress resulting from superoxide. Nevertheless, $\mathrm{H}_{2} \mathrm{O}_{2}$ is also toxic to cells and is detoxified into water and oxygen by CAT (Zhu et al., 2010). Plant's ability to activate its defense mechanism against oxidative degradation is a key link in its mechanism of tolerance to unfavorable environmental conditions. Any change in the activity level of one or more antioxidant enzymes influences plant resistance to stressful factors (Bennicelli et al., 2005).

In addition to using the enzymatic antioxidant defense system, plants react to stress by accumulating compatible solutes such asproline (Gzik, 1997), glycinebetaine (Mansour, 1998), carbohydrates (Balibrea et al., 1997), and polyol (Kumar and Bandhu, 2005). One of the common features of compatible solutes is that they can accumulate to high levels without interfering with natural biochemical reactions (Zhang et al., 2004). In fact, they are hydrophilic and can replace water on the surface of proteins, protein complexes or membranes without disrupting their structure and function (Bohnert and Shen, 1999). These compounds can reduce the inhibitory effects of high concentrations of ions on the activities of the enzymes through fixation of proteins, protein complexes, or membranes under environmental stresses (Bohnert and Shen, 1999; Ashraf and Foolad, 2007). Moreover, compatible solutes may act as absorbers of reactive oxygen species (Seckin et al., 2009; An and Liang, 2013). As a non-toxic and protective osmolyte in higher plants, proline is usually involved in tolerance to salinity (Flowers et al., 1986).

\section{Aloe vera and its derivatives}

Aloe vera is a succulent plant species of the genus Aloe. An evergreen perennial, it is a stemless or very short-stemmed plant. The leaves are thick and fleshy. The margin of the leaf is serrated and has small white teeth. It has a variety species. A. vera is considered to be native to Africa. Different species of Aloe vera spread widely in North Africa as well as hot mountains in Africa, Madagascar, and Jordon. Some African native Aloe vera species are very similar to the treen (Royal Botanical Garden, 2014). 
As a medicinal plant, Aloe vera plant is widely used in the medicinal, cosmetics and health sectors. Aloe vera plant contains chemical compounds and strong complexes, vitamins, enzymes, minerals, sugars, lignin, saponin, amino acids, and fats. Due to its many properties in the treatment of various diseases, Aloe vera has a worldwide reputation as a magic or multi-use plant. Some properties of Aloe vera plant include: gastric and duodenal ulcer treatment, ileus treatment, laxative, glucose and cholesterol regulator, kidney stones treatment, improving liver function, hemorrhoid treatment, reducing anemia, treatment of migraines, weight loss, reducing heartburn and brash, anti-stress, providing essential amino acids for the body, eczema treatment, fungicide, fast antipyretic, hair tonic, arthritis treatment, etc (Shelton, 1991).

Aloe vera requires high temperatures, light soil, and intense sunlight for growth and reproduction. Excessive accumulation of water around the root is a limiting factor in the growth of Aloe vera, which can result in root rot and attack of pathogenic fungi to the root of the plant (Royal Botanical Garden, 2014). The low temperature, especially the temperature that causes the plant's gel to freeze, can disrupt all the meristem activities of the plant, and thereby prevent it from survival. High salinity is another limiting factor in plant growth.

In the green leaf area of the Aloe vera, 20 species of anthraquinone, which is a phenolic compound, are found. Aloin and emodin are two well-known anthraquinones in Aloe vera. In addition to being known as a strong antibacterial and antiviral, these two compounds can prolong cell life and prevent live cell death. These two compounds contribute to destroy cancer cells, heal wounds, and strengthen the immune system. Two types of aloin, i.e. barbaloin and nataloin, with nitric acid under thermal condition and with fumingic acid under cold condition, produce oxalic acid, aloetic acid, and chrismatic acid.

Considering the importance and great properties of the Aloe vera plant and its cultivation at a very broad level, it is obvious that in order to have a healthy plant containing large quantities of white chemicals, the plant should provide with proper nutrition through supplying all nutrients and water needs as well as suitable temperature conditions. According to the plant nutrition science, it can be achieved the maximum plant growth as well as the best possible quality of the elements by providing maximum nutrients with appropriate concentrations, adjusting the $\mathrm{pH}$ of the food solution, the proper ratio of minerals to organic elements in the plant nutrition. With a proper nutrition, it can maximize the concentrations of the resulted elements from the plant, which will result in cost savings and increased yield per unit area. Maximum production quality and plant growth can be achieved by using chemical and organic codes.

\section{References review}

Many studies have shown that not only does silicon improve plant growth and yield (Ahmed et al., 2011; Balakhninaet al., 2012; Guneset al., 2007a; Ma et al., 2004; Savant et al., 1997; Hattori et al., 2005) but it also plays a key role in activating the enzymatic and non-enzymatic defense mechanisms of plants against biotic and abiotic stresses (Richmond and Sussman, 2003; Ma and Yamaji, 2006; Liang et al., 2007; Kim et al., 2011; Van Bockhaven et al., 2013). Molecular and biochemical mechanisms of silicon in relation to increases in plant resistance to stress are not well-known and require further research (Sivanesan and Park, 2014). Therefore, the present research intended to study the effect of silicon on some of the important antioxidant enzymes and phytochemical compounds in Aloe vera. 
Murillo-Amador et al. (2014) investigated the effect of salinity on minerals and various chemicals found in Aloe vera. They investigated the effect of various concentrations of sodium chloride on proline concentration, phosphor-phenyl carboxylate enzyme in parenchyma and chlorophyll. They concluded that when salinity increased, the concentrations of proline and pepase enzyme increased in both parenchyma and chlorophyll. However, with increasing salinity, total protein concentration increased in parenchyma but decreased in chlorophyll.

\section{Materials and methods}

\section{The greenhouse location}

The experiment was carried out in No. 256, the greenhouse townhouse, in the Hashtgerd region located West of Alborz province in the Iran. Hashtgerd is located in the central part of Savojbolagh.

\section{Hydroponic greenhouse}

The greenhouse is of Dutch type with two layer coating of UV and anti-fog, and has a gas-fired heating system, fan cooling system, and side and ceiling valves. The greenhouse is equipped with an automatic temperature and humidity control system. The moisture and temperature data are measured by sensors and thermometers and instantaneously transmitted to the central processing system of the greenhouse. If the greenhouse humidity exceeds the limit, the processing center will immediately order the automatic opening of the side and ceiling valves, with the help of control switches. When the moisture content reaches the optimum level, the valves closing command is again given. In the case of insufficient moisture, the fog system automatically adjusts the moisture content. In the case of temperature sensors, if the temperature exceeds the programmed limit, the fan and pad system start until the desired temperature reaches. If the greenhouse temperature is lower than the desired temperature, the greenhouse processing unit will order turning on the heating system (gas-fired heaters). All information sent to the processing center is evaluated and, given the temperature and humidity requirements, the operating instructions are executed by the micro-switches. The irrigation system consists of two 5000-L reservoir tanks, a pumping system including pump and its related connections, as well as transmission lines and a nutritional solution collection system that is spaced $50 \mathrm{~cm}$ from each other. The whole greenhouse floor is concreted, sloped, and drained. The hydroponic greenhouse is of closed type, and nutritional solution is collected into the reservoir after watering the pots and restored to the system.

At first, 60 pots were placed in greenhouses 1 and 2 (30 pots per greenhouse). It should be noted that the greenhouses were divided into two equal parts of five $500 \mathrm{~m}$ by polyethylene coating.

A completely randomized factorial design including 2 temperature treatments, 2 silica fertilizer treatments, 5 silica surface treatments, each with three replications, and a total of 60 plots, were designed and implemented.

\section{Aloe vera cultivation}

60 Aloe vera plant of Aloe barbadensis Mill variety were taken. After applying the fertilizer treatments during cold stress treatment, 30 pots were placed at $25^{\circ} \mathrm{C}$ (control) and 30 pots at $4{ }^{\circ} \mathrm{C}$ (stress), and then fertilizer side-treatments were applied. 


\section{Irrigation time}

Each pot is irrigated for half an hour with two drippers with a flow rate of $4 \mathrm{~L} / \mathrm{h}$. Three irrigation were determined along with two hydroponic nutritional solutions at 10 am and $17 \mathrm{pm}$.

\section{Sampling}

Step 1: Before the temperature was reduced, sampling from the second leaves was performed in order to investigate and compare the effect of temperatures of $25^{\circ} \mathrm{C}$ and $4{ }^{\circ} \mathrm{C}$ in greenhouse No. 2. According to standard condition, the samples were sent to the Standard Reference Laboratory of Iran to perform measurement tests of SOD, CAT, glucomannan, mannose, and aloin.

Step 2, after applying cold stress: According to the previous research (Liang et al., 2008), the activity of SOD and catalase increased and reached the maximum level in rape and wheat after 7 and 4 days of cold stress, respectively. Nayyar and Walia (2003) studied the 14-day seedlings under cold stress. They observed that reducing temperature to $4{ }^{\circ} \mathrm{C}$ increased the ion permeation, while adaptation to a low temperature of $10^{\circ} \mathrm{C}$ for 6 days reduced the production of hydrogen peroxide LTS.

In order to compare the effect of reducing temperature in the greenhouse No. 2 after 7 days, sampling was carried out and the samples were sent to the Laboratory of National Genetic Bank Center (Standard Reference Laboratory, Iran), according to standard conditions. The comparison of fertilizer treatments means as well as the fertilizer treatment and temperature interaction are specified in Table 3. Temperatures of $25{ }^{\circ} \mathrm{C}$ and $4{ }^{\circ} \mathrm{C}$ correspond to before and after applying the cold stress, respectively (Control $=25^{\circ} \mathrm{C}$, cold stress $\left.=4^{\circ} \mathrm{C}\right)$. The zero concentration of silica $(\mathrm{ppm}=0)$ is related to the control treatment, where no fertilizer treatment was applied.

\section{Nutritional solution}

At the first of the season, the temperatures of the both greenhouses were set at $25^{\circ} \mathrm{C}$. Then the pots were irrigated with water containing nutritional solution. Irrigation with water containing nutritional solution was performed daily, at 10 am and $17 \mathrm{pm}$, for $30 \mathrm{~min}$. The nutritional solution used for the plant growth was modified Hoagland hormone in a hydroponic culture system (Table 1).

Table 1. The morning and evening nutritional solution

\begin{tabular}{c|c}
\hline Morning nutritional solution & Evening nutritional solution \\
\hline $\mathrm{N}(235 \mathrm{ppm})$ & $\mathrm{Ca}(14 \mathrm{ppm})$ \\
$\mathrm{P}(73 \mathrm{ppm})$ & $\mathrm{K}(65 \mathrm{ppm})$ \\
$\mathrm{K}(110 \mathrm{ppm})$ & $\mathrm{Fe}(1.8 \mathrm{ppm})$ \\
$\mathrm{Mg}(22 \mathrm{ppm})$ & \\
$\mathrm{Zn}(1.36 \mathrm{ppm})$ & \\
$\mathrm{B}(1.1 \mathrm{ppm})$ & \\
$\mathrm{Mn}(2.4 \mathrm{ppm})$ & \\
\hline
\end{tabular}

One month after planting Aloe vera in pots and using nutritional solutions in morning and evening, fertilizer treatments were applied to the pots every Monday. To this end, 
after morning irrigation, some fertilizer was mixed with $20 \mathrm{ml}$ of distilled water and added to the pots by hand. The numbering of the pots is done in a complete random manner. The zero concentration of silica was considered as control treatment. One month after treatments were applied, the temperature of greenhouse No. 2 was set at $4{ }^{\circ} \mathrm{C}$, and this greenhouse was exposed to cold stress. After reducing temperature, fertilizer treatments were applied to the both greenhouses.

\section{Planting Aloe vera and applying silicon fertilizer treatments}

An experiment was conducted in the greenhouse town of Hashtgerd in Karaj on 60 (Aloe barbadensis Miller) plants with the average height of $15 \mathrm{~cm}$ and each with at least three leaves. They were planted in $18 * 14.7 \mathrm{~cm}$ polyethylene pots filled with a perlite and coco peat mix in a hydroponic system. The pots were automatically irrigated and fed with a standard nutrient solution once in the morning and another time in the afternoon. In addition, they were treated once a week with various levels of silicon ( 0 [in the control], and 500, 1000, 1500, and $2000 \mathrm{ppm}$ ) using potassium silicate and silicic acid.

\section{Applying cold stress}

The average temperature of the greenhouse was first set at $25^{\circ} \mathrm{C}$. After the plants were grown under normal conditions for three months, 30 of the pots were exposed to cold stress at $4{ }^{\circ} \mathrm{C}$ for seven days. 3. Sampling and measuring phytochemical and medicinal properties of Aloe vera

Following the cold stress, the second leaf of every plant was simultaneously removed and the samples were transferred to the lab in ice bags. The leaves were washed with distilled water, their surfaces were dried, and activities of the antioxidant enzymes (including SOD and CAT) and of the compatible solutes (including mannose, glucomannan, as well as aloin [as a medicinal compound]) were evaluated as follows.

\section{Measuring activities of the antioxidant enzymes}

To prepare enzymatic extracts (Sairamet al., 2002), $0.5 \mathrm{~g}$ of the frozen leaf sample was turned in to a homogeneous powder in a mortar with $10 \mathrm{ml}$ of cold $0.1 \mathrm{M}$ phosphate buffer $(\mathrm{pH}=7.8)$ containing $0.5 \mathrm{mmol}$ EDTA. The homogenized powder was transferred to centrifuge tubes and then centrifuged at $13000 \mathrm{rpm}$ for $30 \mathrm{~min}$ at $4{ }^{\circ} \mathrm{C}$. Using a spectrophotometer at $25^{\circ} \mathrm{C}$, enzymatic measurement of the supernatant was carried out with three replications.

SOD activity was measured based on the ability to prevent photo reduction of Nitro BlueTetrazolium (NBT) chloride using the method introduced by Giannopolitis and Ries (1977). Three $\mathrm{mL}$ of reaction solution containing $13 \mathrm{mmol}$ of methionine, $75 \mu \mathrm{mol}$ of NBT chloride, $2 \mu \mathrm{mol}$ of riboflavin, $50 \mathrm{mmol}$ phosphate buffer, and $50 \mu \mathrm{l}$ of the extracted enzyme was exposed to two 15-Watt fluorescent light bulbs (with light intensity of 1000 lux) for $10 \mathrm{~min}$ at a distance of $20 \mathrm{~cm}$. The reaction began when light was turned on and ended when it was turned off. The reaction solution was then covered with a black cloth until absorbance was measured. Absorbance was read at $560 \mathrm{~nm}$ using a model BT 600 spectrophotometer. One unit of SOD activity was considered to be the amount of the enzyme that could prevent photo reduction of NBT ( $\rho$-nitro blue tetrazolium chloride) by 50 percent (Liang et al., 2008). 
CAT activity was determined according to Chance and Maehly (1955). The CAT reaction solution containing $15 \mathrm{mmol}$ of $\mathrm{H}_{2} \mathrm{O}_{2}, 50 \mathrm{mmol}$ of phosphate buffer, and $100 \mu \mathrm{l}$ of the extracted enzyme were used. The reaction began by adding the enzyme and, after $1 \mathrm{~min}$, reduction in $\mathrm{H}_{2} \mathrm{O}_{2}$ absorbance at $240 \mathrm{~nm}$ in $1 \mathrm{~min}$ was recorded. In this method, one unit of CAT activity was considered to be the amount of the enzyme that could oxidize one mmol of $\mathrm{H}_{2} \mathrm{O}_{2}$ in $1 \mathrm{~min}$.

\section{Measuring compatible solutes}

The method introduced by Dubois et al. (1956), which is based on acidic hydrolysis of soluble sugars and production of furfural that generates a colored complex with phenol, was used to measure mannose. The leaf sample $(0.2 \mathrm{~g})$ was ground and homogenized in $4 \mathrm{ml}$ of $25 \mathrm{mM}$ sodium phosphate buffer $(\mathrm{pH}=6.8)$. The reaction solution was prepared by pouring $0.5 \mathrm{ml}$ of the extracted sugar solution, $0.5 \mathrm{ml}$ of $5 \%$ phenol, and $2.5 \mathrm{ml}$ of pure sulfuric acid in a test tube. The reaction began with the addition of the sulfuric acid. It was an exothermic reaction andproducedan orange color. After the solution cooled, absorbance was read at $490 \mathrm{~nm}$ using the spectrophotometer. The standard curve was drawn using various concentrations of mannose from 0 to $20 \mu \mathrm{g} / \mathrm{ml}$.

To measure glucomannan, the method introduced by Eberendu et al. (2005) was used. This method is based on measuring changes in the Congo red indicator made by the presence of glucomannan in the reaction. The leaf sample $(40 \mathrm{mg})$ was transferred to each conical polypropylene tube, $20 \mathrm{ml}$ of distilled water was added to the tube and it was shaken at $200 \mathrm{rpm}$ for $4 \mathrm{~h}$. Forty $\mathrm{ml}$ of the Congo red indicator (sodium 4,4_diphenyl-. 2,2_diazo-bis-1-naphtlamino-4-sulfonate) was then poured into the tube, the tube was left at room temperature for 20 minutes, and absorbance was read at $540 \mathrm{~m}$. Standard solutions containing Aloe vera polysaccharides were prepared using the Waller et al. (1978) method. After the standard curve was drawn, glucomannan content was read in $\mathrm{mg} / \mathrm{L}$.

\section{Measuring aloin}

To measure aloin concentration in the green skin of Aloe vera leaves, the spectrophotometric method was used (Ellaithy et al., 1984). One gram of the green leaf tissue was ground and homogenized by liquid nitrogen in a crucible, $10 \mathrm{ml}$ of methanol extraction solvent was added, and the solution was kept in a refrigerator at $4{ }^{\circ} \mathrm{C}$ for $24 \mathrm{~h}$. The solution containing aloin was then centrifuged at $10,000 \mathrm{rpm}$ for $10 \mathrm{~min}$. The supernatant was passed through $0.45 \mu \mathrm{m}$ filter paper, $2 \mathrm{~mL}$ of the magnesium acetate was added, and light absorption intensity was read at $262 \mathrm{~nm}$.

\section{Statistical analysis of the data}

The factorial experiment with two factors (silicon at five concentration levels and temperature at the two levels of normal and low temperature) was carried out using a completely randomized design with three replications and the data was analyzed employing SAS. Before performing ANOVA, normality of the data was tested using the Kolmogorov-Smirnov (K-S) test. 


\section{Results}

Results of ANOVA indicate that the effects of silicon and cold stress on levels of enzyme activity and on phytochemicals including SOD, CAT, glucomannan, mannose, and aloin, were significant at the 0.01 level $(\mathrm{P}<0.01)$. The mutual effects of silicon and cold stress were also significant at the 0.01 level (Table 2).

Table 2. Results of ANOVA related to biochemical properties

\begin{tabular}{c|c|c|c|c|c|c}
\hline Source of variance & df & $\begin{array}{c}\text { SOD }\left(\mathbf{U m g}^{-1}\right. \\
\text { of protein) }\end{array}$ & $\begin{array}{c}\text { CAT }\left(\mathbf{U m g}^{-1}\right. \\
\text { of protein) }\end{array}$ & $\begin{array}{c}\text { Glucomannan } \\
\left(\mathbf{m g ~ L}^{-1}\right)\end{array}$ & $\begin{array}{c}\text { Mannose } \\
\left(\mathbf{m g ~ L}^{-1}\right)\end{array}$ & $\begin{array}{c}\text { Aloin } \\
(\%)\end{array}$ \\
\hline The Si treatment & 4 & $82.680 * *$ & $0.5597 * *$ & $0.000654 * *$ & $0.0429 * *$ & $0.441 *$ \\
Temperature & 1 & $17.168 * *$ & $0.4359 * *$ & $0.3824 * *$ & $21.780 * *$ & $695.641 \mathrm{~ns}$ \\
The Si ${ }^{*}$ temperature treatment & 4 & $57.187 * *$ & $0.230 * *$ & $0.000381 * *$ & $0.02532 * *$ & $0.0941 * *$ \\
Error & 20 & & & & \\
CV $(\%)$ & - & 0.867 & 1.183 & 2.27 & 1.162 & 0.584 \\
\hline
\end{tabular}

The symbols *,**, and ns mean significance at $\mathrm{P}<0: 05$ and $\mathrm{P}<0.01$ levels and not significant, respectively, and the numbers in the table are means of squares of the effects

The highest level of SOD activity $(34.86 \mu \mathrm{mol} / \mathrm{min})$ belonged to the $2000 \mathrm{ppm}$ silicon concentration and the lowest $(27.68 \mu \mathrm{mol} / \mathrm{min}$ ) to the control (no silicon concentration). SOD activity at silicon concentrations of 500, 1000, 1500, and 2000 ppm increased by $17.3,20.5,23.4$, and 25.9 percent, respectively, compared to the control (Table 3). The higher level of CAT activity was also observed in the treatments with high silicon concentrations (1500 and $2000 \mathrm{ppm})$ and the lowest in the control. CAT activity at silicon concentration of $2000 \mathrm{ppm}(2.37 \mu \mathrm{mol} / \mathrm{min})$ was about $37 \%$ higher than that of the control $(1.72 \mu \mathrm{mol} / \mathrm{min})$.

Table 3. Comparison of the means of the main effects on antioxidant activities

\begin{tabular}{|c|c|c|c|c|c|c|}
\hline $\begin{array}{c}\text { Source of } \\
\text { variation }\end{array}$ & Treatment & \begin{tabular}{|c|} 
SOD $\left(\mathrm{Umg}^{-1}\right.$ \\
of protein)
\end{tabular} & $\begin{array}{l}\text { CAT (Umg-1 } \\
\text { of protein) }\end{array}$ & $\begin{array}{c}\begin{array}{c}\text { Glucomannan } \\
\left(\mathrm{mg} \mathrm{L}^{-1}\right)\end{array} \\
\end{array}$ & $\begin{array}{l}\text { Mannose } \\
\left(\mathrm{mg} \mathrm{L}^{-1}\right)\end{array}$ & $\begin{array}{c}\text { Aloin } \\
(\%)\end{array}$ \\
\hline \multirow{2}{*}{ Temperature } & Control $\left(25^{\circ} \mathrm{C}\right)$ & $27.81 \mathrm{~b}$ & $1.97 \mathrm{~b}$ & $0.35 \mathrm{a}$ & $0.75 b$ & $11.10 \mathrm{a}$ \\
\hline & Cold Stress $\left(4^{\circ} \mathrm{C}\right)$ & $37.22 \mathrm{a}$ & $2.14 \mathrm{a}$ & $0.31 \mathrm{~b}$ & $1.95 \mathrm{a}$ & $4.29 b$ \\
\hline \multirow{5}{*}{ Concentration } & 0 ppm & $27.68 \mathrm{~b}$ & $1.72 \mathrm{~b}$ & $0.31 \mathrm{c}$ & $1.28 \mathrm{c}$ & $7.44 b$ \\
\hline & $500 \mathrm{ppm}$ & $32.49 \mathrm{a}$ & $1.99 \mathrm{ab}$ & $0.33 \mathrm{~b}$ & $1.32 \mathrm{bc}$ & $7.58 \mathrm{bc}$ \\
\hline & 1000 ppm & $33.38 \mathrm{a}$ & $2.07 \mathrm{ab}$ & $0.33 \mathrm{ab}$ & $1.33 \mathrm{~b}$ & $7.70 \mathrm{~b}$ \\
\hline & $1500 \mathrm{ppm}$ & $32.18 \mathrm{a}$ & $2.36 \mathrm{a}$ & $0.33 \mathrm{ab}$ & $1.36 \mathrm{~b}$ & $7.83 a b$ \\
\hline & 2000 ppm & $34.86 \mathrm{a}$ & $2.37 \mathrm{a}$ & $0.34 \mathrm{a}$ & $1.45 \mathrm{a}$ & $7.97 \mathrm{a}$ \\
\hline
\end{tabular}

Means with similar Latin letters are not significantly different

Comparison of the means of the phytochemicals including glucomannan and mannose in Aloe vera indicated that cold stress was an influential factor on them so that their mean concentration in samples exposed to cold stress was significantly lower. These results suggest stoppage or reduction of plant metabolic processes. The average contents of glucomannan and mannose in plants not treated with cold stress were about 13 and 15 percent greater, respectively, compared to those that were exposed to cold stress. The aloin content in plants not exposed to cold stress was higher, compared to 
plants that were treated with cold stress; however, the difference was not statistically significant.

Investigating the interaction between temperature and concentration of silicon on the activities of antioxidants (Table 4) indicates that at $25{ }^{\circ} \mathrm{C}$ or control temperature, increasing the concentration of silicon results in the increase in the activities of CAT and SOD enzymes as well as the concentrations of glucomannan, mannose, and aloin, and there is an ascending trend. This suggests that silicon has increased the activities of antioxidant enzymes in the plant by improving the nutritional value of Aloe vera plant under normal condition. Under stress temperature or at $4{ }^{\circ} \mathrm{C}$, the activities of SOD and CAT enzymes increased with the different levels of silicon fertilizer treatments, and there was a significant difference when compared with control group. The highest and lowest values of SOD activity was related to $2000 \mathrm{ppm}$ and $1000 \mathrm{pp}$, respectively. There were no significant differences between $500 \mathrm{ppm}$ and $1000 \mathrm{ppm}$ silicon treatments. That is, both have the same effect on SOD enzyme activity. The highest increase of CAT enzyme activity was due to $2000 \mathrm{ppm}$ fertilizer treatment, which has a significant difference with the control group. Under cold stress or at $4{ }^{\circ} \mathrm{C}$, the SOD enzyme activity increased by about $37 \%$, using $2000 \mathrm{ppm}$ silicon fertilizer treatment, compared with fertilizer treatment at $25{ }^{\circ} \mathrm{C}$, indicating the effect of the temperature of $4{ }^{\circ} \mathrm{C}$ on the sudden increase of SOD activity at this temperature (the interaction between $\mathrm{Si}$ and stress temperature).

Investigating the interaction between control temperature and silicon concentration as well as stress temperature or $4{ }^{\circ} \mathrm{C}$ and silicon concentration on the CAT enzyme activity indicates that CAT activity increased under the stress temperature by $11 \%$ more than control temperature. This indicates the effect of the stress temperature and the concentration of silicon on the increase of activity of CAT antioxidant enzyme, which in turn shows the effect of $\mathrm{Si}$ on this enzyme. These two suggest the stimulation of the defense system and the increase in the activity of antioxidant enzymes. Investigating the interactions between temperature and concentration of silicon on the concentration of aloin indicates that temperature has a significant effect on the concentration of aloin. As the temperature decreases, the aloin concentration decreases, and when the temperature increases, the aloin concentration increases under the influence of the concentration of silicon.

Table 4. Comparison of the interaction effects on antioxidant activities

\begin{tabular}{c|c|c|c|c|c|c}
\hline Temperature & Si Concentration & $\begin{array}{c}\text { CAT (Umg-1 } \\
\text { of protein) }\end{array}$ & $\begin{array}{c}\text { SOD (Umg } \\
\text { of protein) }\end{array}$ & $\begin{array}{c}\text { Aloin } \\
(\boldsymbol{\%})\end{array}$ & $\begin{array}{c}\text { Mannose } \\
(\boldsymbol{\%})\end{array}$ & $\begin{array}{c}\text { Glucomannan } \\
(\boldsymbol{\%})\end{array}$ \\
\hline \multirow{5}{*}{ Control } & $0 \mathrm{ppm}$ & $25.51 \mathrm{~d}^{*}$ & $1.84 \mathrm{c}$ & $0.38 \mathrm{c}$ & $1.71 \mathrm{c}$ & $10.73 \mathrm{~b}$ \\
& $500 \mathrm{ppm}$ & $27.19 \mathrm{~cd}$ & $1.91 \mathrm{~b}$ & $0.39 \mathrm{~b}$ & $0.75 \mathrm{c}$ & $10.95 \mathrm{~b}$ \\
& $1000 \mathrm{ppm}$ & $27.89 \mathrm{~cd}$ & $1.92 \mathrm{~b}$ & $0.41 \mathrm{ab}$ & $0.74 \mathrm{c}$ & $11.1 \mathrm{ab}$ \\
& $1500 \mathrm{ppm}$ & $28.18 \mathrm{c}$ & $1.96 \mathrm{~b}$ & $0.41 \mathrm{ab}$ & $0.76 \mathrm{c}$ & $11.28 \mathrm{a}$ \\
& $2000 \mathrm{ppm}$ & $29.31 \mathrm{c}$ & $2.24 \mathrm{ab}$ & $0.43 \mathrm{a}$ & $0.78 \mathrm{c}$ & $11.55 \mathrm{a}$ \\
\hline \multirow{5}{*}{ Cold Stress } & $0 \mathrm{ppm}$ & $28.86 \mathrm{c}$ & $1.59 \mathrm{c}$ & $0.24 \mathrm{~d}$ & $0.85 \mathrm{~b}$ & $4.16 \mathrm{c}$ \\
& $500 \mathrm{ppm}$ & $37.79 \mathrm{~b}$ & $2.06 \mathrm{~b}$ & $0.24 \mathrm{~d}$ & $0.89 \mathrm{~b}$ & $4.21 \mathrm{c}$ \\
& $1000 \mathrm{ppm}$ & $38.87 \mathrm{~b}$ & $2.22 \mathrm{ab}$ & $0.25 \mathrm{~d}$ & $0.92 \mathrm{ab}$ & $4.31 \mathrm{c}$ \\
& $1500 \mathrm{ppm}$ & $40.18 \mathrm{a}$ & $2.35 \mathrm{ab}$ & $0.25 \mathrm{~d}$ & $0.96 \mathrm{a}$ & $4.38 \mathrm{c}$ \\
& $2000 \mathrm{ppm}$ & $40.41 \mathrm{a}$ & $2.50 \mathrm{a}$ & $0.25 \mathrm{~d}$ & $2.13 \mathrm{a}$ & $4.40 \mathrm{c}$ \\
\hline
\end{tabular}


Investigating the interactions between temperature and concentration of silicon on mannose indicates that the concentration of mannose has increased due to temperature reduction and increase in the concentration of silicon fertilizer. Investigating the trends of glucomannan changes suggests that the temperature reduction has resulted in the decrease of glucomannan concentration. That is, the concentration of glucomannan decreased under stress condition. At $25{ }^{\circ} \mathrm{C}$, the concentration of glucomannan is increasing due to the increase in silicon concentration. At $4{ }^{\circ} \mathrm{C}$, the increase in consumed level of silicon leads no significant difference in glucomannan concentration. Perhaps one of the reasons is that glucomannan is converted into simpler sugars to be consumed and moderating the cold stress at $4{ }^{\circ} \mathrm{C}$.

\section{Discussion}

In order to investigate the effect of stress temperature $\left(4{ }^{\circ} \mathrm{C}\right)$ on CAT, SOD, mannose, glucomannan, and aloin components as phytochemical and medicinal parameters of Aloe vera plant, as well as comparing it with optimum growth or control temperature $\left(25^{\circ} \mathrm{C}\right)$, and also studying the effect of type of the fertilizer, two type of silica fertilizer, i.e. salicylic acid and potassium silicate, with five levels of fertilizer treatments including 0, 500, 1000, 1500, and $2000 \mathrm{ppm}$ for 60 potted Aloe vera plants under hydroponics cultivation were used. The temperatures of $4{ }^{\circ} \mathrm{C}$ and $25{ }^{\circ} \mathrm{C}$ were selected as stress and control or optimal conditions for plant growth, respectively. Different concentrations or treatment levels were tested for both plants exposed to $4{ }^{\circ} \mathrm{C}$ and $25{ }^{\circ} \mathrm{C}$. Therefore, the interaction between temperature and silica treatment levels can be investigated. The results show that the concentrations of CAT and SOD increased due to cold stress and silica fertilizer treatment, when compared to $25{ }^{\circ} \mathrm{C}$. Increasing SOD activity at $4{ }^{\circ} \mathrm{C}$ directly related to increase in silica concentration. That is, at $4{ }^{\circ} \mathrm{C}$, with increasing silica concentration, the activity of SOD increased, and its most activity was in the concentration of $2000 \mathrm{ppm}$, which was $34.86 \mathrm{Vmg}^{-1}$ of protein.

At $25^{\circ} \mathrm{C}$, application of fertilizer treatment could increase the SOD concentration in the plant, which has an activity of $27.81 \mathrm{Vmg}^{-1}$ of protein. The examination of these two values indicates that the stress temperature $\left(4^{\circ} \mathrm{C}\right)$ triggered the plant's defense system and could increase the SOD concentration by about 6.99 units, when compared to $25^{\circ} \mathrm{C}$. This increase is about $25.13 \%$.

Comparison of the means showed that the highest SOD and CAT activities were those of the cold stress treatment. Many studies have indicated that there is a direct relationship between antioxidant enzyme activity and plant resistance to cold stress (Javadian et al., 2010; Luo et al., 2011; Radyuk et al., 2009). Mean SOD activity in samples exposed to cold stress was 33.8 percent higher than that of the samples not exposed to cold stress. CAT was also influenced by cold stress, and its mean activity in samples exposed to cold stress was about $8.6 \%$ higher than that of the samples not treated with cold stress. These results indicated plant defense mechanism against cold stress.

Comparison of the means of various silicon concentrations revealed that there were significant differences between the control and the treatments. However, the differences between the various levels of silicon concentrations were not significant. This suggests that presence of silicon, even at low amounts, plays a significant role in improving and activating plant antioxidant defense system. 
The results show the positive effect of silicon in the process of antioxidant synthesis. Comparison of the means of glucomannan, mannose, and aloin contents at various silicon concentrations showed that there was a direct relationship between silicon concentration and the contents of the phytochemicals so that their lowest contents were observed in the control treatment and the highest at silicon concentration of $2000 \mathrm{ppm}$.

As shown in the ANOVA table, the application of the 7-day cold treatment significantly affected antioxidant activity levels probably because of the positive effects that silicon had in the mechanism of inducing resistance in plants against the cold stress (Ma and Yamaji, 2006; Kim et al., 2011). Interaction effects of temperature and silicon concentration showed that the highest levels of antioxidant enzyme activity were observed at silicon concentrations of 1500 and $2000 \mathrm{ppm}$ and the lowest in the control (no silicon application). In a similar study, Zhu et al. (2006) stated that silicon increased plant resistance against cold and frost.

The greater SOD and CAT contents were observed at high silicon concentrations, which indicated the role silicon played in the activities of these antioxidants. In a similar study, Gunes et al. (2008) reported that, depending on plant type and variety, silicon influenced the levels of antioxidant enzyme activity, especially those of SOD and CAT. They stated that plants increased their antioxidant activities under stress conditions to be able to neutralize or minimize the stress. They noticed that applying the silicon treatment enhanced plant defense system through increasing antioxidant synthesis and, hence, modified the destructive effects resulting from the stress. Liang et al. (2008) reported that silicon application under cold stress down to $-5^{\circ} \mathrm{C}$ increased SOD activity in wheat. They demonstrated that SOD activity increased and reached its highest level following cold storage treatment for four days. Fahimirad et al. (2013) noticed that SOD activity reached its highest level after applying cold stress for 7 days in colza.

Plants usually respond by accumulating compatible solutes such as soluble sugars, carbohydrates, and polyol. Study of the trend of changes in the phytochemicals glucomannan, mannose, and aloin caused by cold stress and by concentrations of applied silicon shows that they had their highest concentrations when silicon was applied at $2000 \mathrm{ppm}$. These results are consistent with those of other studies. For example, Duan et al. (2013) reported that silicon improved Dendrobiumn moniliforme resistance against cold stress by increasing free proline, soluble sugars, and soluble protein contents and by decreasing Malone Dialdehyde (MDA) content.

Yin et al. (2013) also reported that applying silicon to sorghum under salt stress could considerably increase the levels of soluble sugars such as sucrose and fructose. Other researchers reported the contradictory results that silicon application decreased the contents of compatible solutes such as proline in various plants (Soylemezoglu et al., 2009; Lee et al., 2010; Tuna et al., 2008; Gunes et al., 2007a). Some researchers consider proline accumulation in plant organs a sign of damages inflicted by stresses and, therefore, reduction in proline content resulting from silicon application can be attributed to the reduction in the damage caused by stresses. Kumar et al. (2010) noticed that pea cultivars resistant to cold had greater contents of proline and ascorbic acid and higher levels of SOD and CAT activities. In general, silicon can enhance the conditions for production of antioxidants and other plant materials, and protect plants against wilting caused by cold stress, through influencing their qualitative and quantitative characteristics including photosynthesis and respiration.

Moreover, the protective role of silicon in plants may also be due to accumulation of polysilicic acids inside cells. There are reports that show silicon can enhance plant 
defense mechanisms through other processes such as accumulation of lignin, phenol compounds and phytoalexins (Epstein, 1999). Results of the present research indicate that increases in anthraquinone and aloin concentrations may be due to accumulation of lignin and phenolic compounds when silicon is applied. At the temperature of $255^{\circ} \mathrm{C}$, suitable photosynthetic conditions were prepared for the plants to produce higher quantities of aloin phenolic materials. Silicon influenced aloin concentration by affecting photosynthetic performance of Aloe vera and through inducing deposition of materials inside cells. At the temperature of $45^{\circ} \mathrm{C}$, silicon was able to increase the aloin content of plants compared to the control through stimulating the defense system of the plants and by increasing their photosynthetic ability.

\section{Conclusions}

Cold stress increased antioxidant enzymes and reduced metabolic activities of Aloevera. As an agent activating enzymatic and non-enzymatic defense system, silicon plays a key role in inducing plan resistance against cold stress. Applying silicon fertilizer augmented activities of SOD and CAT, enhanced contents of compatible solutes such as glucomannan and mannose, and also increased aloin concentration in Aloevera. The findings of the present research show the importance of applying silicon fertilizers in increasing plant resistance, in reducing damages caused by cold stress, and consequently, in achieving sustainable agricultural production.

Considering the effect of $\mathrm{Si}$ on the induction of plant defense system against the environmental stress, it is suggested that the effects of elements such as cobalt $(\mathrm{K})$ on the activity of oxidative enzymes under cold and saline stresses would be tested. The effect of Si as spraying on the growth factors and antioxidant components of the plant in order to accelerate the absorption of the element and to reduce the stress of cold and drought stresses under sudden stresses can also be investigated.

Acknowledgements. This work was financially supported by the Zarafshan manufacturer of fertilizer and pesticide, Iran. The authors are grateful to Dr. Mehdi Tehrani of Institute of Soil and Water Research and Dr. Babak Motesharezadeh of Tehran University, Iran. Also, this research received no specific grant from any funding agency in the public, commercial or not-for-profit sectors.

\section{REFERENCES}

[1] Adam, S., Murthy, S. (2014): Effect of Cold Stress on Photosynthesis of Plants and Possible Protection Mechanisms. - In: Gaur, P. S. (ed.) Approaches to Plant Stress and their Management. Springer, New Delhi.

[2] Ahmed, M., Hassen, F. U., Qadeer, U., Aslam, M. A. (2011): Silicon application and drought tolerance mechanism of sorghum. - Africa Journal Agriculture Research 6: 594607.

[3] Ali, A. A., Alqurainy, F. (2006): Activities of Antioxidants in Plants under Environmental Stress. - In: Motohashi, N. (ed.) The Lutein-Prevention and Treatment for Diseases. Transworld Research Network Press, Trivandrum, India.

[4] Allen, R. D. (1995): Dissection of oxidative stress tolerance using transgenic plants. Plant Physiol 107: 1049-1054.

[5] Alsher, R. G., Donahue, J. L., Cramer, C. L. (1997): Reactive oxygen species and antioxidants: relationship in green cells. - Physiol Plant 100: 224-233. 
[6] An, Y. Y., Liang, Z. S. (2013): Drought tolerance of Periploca sepium during seed germination: antioxidant defense and compatible solutes accumulation. - Acta Physiol Plant 35: 959-967.

[7] Asada, K. (2006): Production and scavenging of reactive oxygen species in chloroplasts and their functions. - Plant Physiol 141: 391-396.

[8] Ashraf, M., Foolad, M. R. (2007): Roles of glycine betaine and proline in improving plant abiotic stress resistance. - Environ Exp Bot 59: 206-216.

[9] Bafana, A., Dutt, S., Kumar, A., Kumar, S., Ahuja, P. S. (2011): The basic and applied aspects of superoxide dismutase. - J Mol Catal B Enzym 68(2): 129-138.

[10] Balakhnina, T. I., Bennicelli, R. P., Stêpniewska, Z., Stêpniewski, W., Fomina, I. R. (2010): Oxidative damage and antioxidant defense system in leaves of Viciafaba major L. cv. Bartom during soil flooding and subsequent drainage. - Plant Soil 327: 293-301.

[11] Balakhnina, T. I., Matichenkov, V. V., Wlodarczyk, T. M., Borkowska, A., Nosalewicz, M., Fomina, I. R. (2012): Effects of silicon on growth processes and adaptive potential of barley plants under optimal soil watering and flooding. - Plant Growth Reg. DOI: 10.1007/s10725-012-9658-6.

[12] Balibrea, M. E., Rus-Alvarez, A. M., Bolarfn, M. C., Pérez-Alfocea, F. (1997): Fast changes in soluble carbohydrates and proline contents in tomato seedlings in response to ionic and non-ionic iso-osmotic stresses. - J Plant Physiol 151: 221-226.

[13] Bennicelli, R. P., Balakhnina, T. I., Szajnocha, K., Banach, A. (2005): Aerobic conditions and antioxidative system of Azolla caroliniana Willd in the presence of $\mathrm{Hg}$ in water solution. - Int Agrophysic 19: 27-30.

[14] Bohnert, H. J., Shen, B. (1999): Transformation and compatible solutes. - Sci Hortic 78: 237-260.

[15] Chance, B., Maehly, A. (1955): Assay of catalase and peroxidase. - Methods in Enzymology 2: 764-817.

[16] Duan, X., Tang, M., Wang, W. (2013): Effects of silicon on physiology and biochemistry of dendrobium moniliforme plantlets under cold stress. - Agric Biotechnol 2: 18-21.

[17] Dubois, M., Gilles, K. A., Hamilton, J. K., Rebes, P. A., Smith, P. A. (1956): Colorimetric Method for Determination of Sugars and Related Substrates, Anal. - Chem. 28: 350-356.

[18] Eberendu, A. R., Luta, G., Edwards, J. A., McAnalley, B. H., Davis, B. (2005): Quantitative colorimetric analysis of aloe polysaccharides as a measure of Aloe vera quality in commercial products. - AOAC International 88: 684-691.

[19] Ellaithy, M. M., Sayed, L., Bebawy, L. (1984): Spectrophotometric determination of barbaloin. - An International Journal for Rapid Communication 17(11): 743-750.

[20] Epstein, E. (1999): Silicon. - Annual Review of Plant Physiology 50: 641-664.

[21] Fahimirad, S., Karimzadeh, G., Ghanati, F. (2013): Cold-induced changes of antioxidant enzymes activity and lipid per oxidation in two canola (Brassica napus L.) cultivars. Journal of Plant Physiology and Breeding 3(1): 1-11.

[22] Flowers, T. J., Hajibagueri, M. A., Clipson, N. C. W. (1986): Halophytes. - Q Rev Biol 61: 313-337.

[23] Giannopolitis, C. N., Ries, S. K. (1977): Superoxide dismutase I, occurrence in higher plants. - Plant Physiol 59: 309-314.

[24] Gill, S. S., Tuteja, N. (2010): Reactive oxygen species and antioxidant machinery in abiotic stress tolerance in crop plants. - Plant Physiol Biochem 48: 909-930.

[25] Gunes, A., Ali, I., Bagci, E. G., Pilbeam, D. J. (2007a): Silicon-mediated changes of some physiological and enzymatic parameters symptomatic for oxidative stress in spinach and tomato grown in sodic B toxic soil. - Plant Soil 290: 103-114.

[26] Gunes, A., Inal, A., Bagci, E. G., Coban, S. (2007b): Silicon-mediated changes on some physiological and enzymatic parameters symptomatic of oxidative stress in barley grown in sodic-B toxic soil. - J Plant Physiol164: 807-811. 
[27] Gunes, A., Pilbeam, D. J., Inal, A., Coban, S. (2008): Influence of silicon on sunflower cultivars under drought stress. I: Growth, antioxidant mechanisms and lipid per oxidation. - Common Soil Sci Plant Anal 39: 1885-1903.

[28] Gzik, A. (1997): Accumulation of proline and pattern of $\alpha$-amino acids in sugar beet plants in response to osmotic, water and salt stress. - Environ Exp Bot 36: 29-38.

[29] Halliwell, B. (1984): Oxidative damage, lipid per oxidation and antioxidant protection in chloroplasts. - Chem Phys Lipids 44: 327-340.

[30] Hattori, T., Inanaga, S., Araki, H., An, P., Morita, S., Luxova, M., Lux, A. (2005): Application of silicon enhanced drought tolerance in Sorghum bicolor. - Physiol Plant 123: 454-466.

[31] Javadian, N., Karimzadeh, G., Mahfoozi, S., Ghanati, F. (2010): Cold-induced changes of enzymes, proline, carbohydrates and chlorophyll in wheat. - Russ J Plant Physiol57: 540547.

[32] Jung, S. (2004): Variation in antioxidant metabolism of young and mature leaves of Arabidopsis thaliana subjected to drought, - Plant Science 166: 459-466.

[33] Kim, Y. H., Khan, A. L., Hamayun, M., Kang, S. M., Beom, Y. J., Lee, I. J. (2011): Influence of short-term silicon application on endogenous physiohormonal levels of Oryza sativa L. under wounding stress. - Biol Trace Elem Res 144: 1175-1185.

[34] Kumar, A. P., Bandhu, A. D. (2005): Salt tolerance and salinity effects on plants: a review. - Ecotoxicol Environ Saf 60: 324-349.

[35] Kumar, S., Malik, J., Thakur, P., Kaistha, S., Sharma, K. D., Upadhyaya, H. D., Berger, J. D., Nayyar, H. (2010): Growth and metabolic responses of contrasting chickpea (Cicerari entinum L.) genotypes to chilling stress at reproductive phase. - Acta Phisiol Plant 33(3): 779-787.

[36] Larson, R. A. (1988): The antioxidants of higher plants. - Phytochem 27: 969-978.

[37] Lee, S. K., Sohn, E. Y., Hamayun, M., Yoon, J. Y., Lee, I. J. (2010): Effect of silicon on growth and salinity stress of soybean plant grown under hydroponic system. - Agro for Syst 80: 333-340.

[38] Liang, Y. C., Sun, W. C., Zhu, Y. G., Christie, P. (2007): Mechanisms of siliconmediated alleviation of abiotic stresses in higher plants: a review. - Environ Pollut 147: 422-428.

[39] Liang, Y. C., Zhu, J., Li, Z., Chu, G., Ding, Y., Zhang, J., Sun, W. (2008): Role of silicon in enhancing resistance to freezing stress in two contrasting winter wheat cultivars. Environment and Experimental Botany 64: 286-294.

[40] Liang, Y., Nikolic, M., Bélanger, R., Gong, H., Song, A. (2015): Silicon in Agriculture. Springer, Dordrecht.

[41] Luo, H., Li, H., Zhang, X., Fu, J. (2011): Antioxidant responses and gene expression in perennial ryegrass (Lolium perenne L.) under cadmium stress. - Ecotoxicology 20: 770778.

[42] Ma, J. F., Yamaji, N. (2006): Silicon uptake and accumulation in lower plants. - Trends Plant Sci 11(8): 392-397.

[43] Ma, J. F., Mitani, N., Nagao, S., Konishi, S., Tamai, K., Iwashita, T., Yano, M. (2004): Characterization of the silicon uptake system and molecular mapping of the silicon transporter gene in rice. - Plant Physiology 136: 3284-3289.

[44] Mansour, M. M. F. (1998): Protection of plasma membrane of onion epidermal cells by glycine betaine and proline against $\mathrm{NaCl}$ stress. - Plant Physiol Biochem 36: 767-772.

[45] Murillo-Amador, B., Córdoba-Matson, M. V., Villegas-Espinoza, J. A., HernándezMontiel, L. G., Troyo-Diéguez, E., García-Hernández, J. L. (2014): Mineral content and biochemical variables of Aloe vera L. under salt stress. - PLoS One 9(4): e94870. DOI: 10.1371/journal.pone.0094870.

[46] Nayyar, H., Walia, D. P. (2003): Water stress induced proline accumulation in contrasting wheat genotypes as affected by calcium and abscisic acid. - Biol Plant 46: 275-279. 
[47] Radyuk, M. S., Domanskaya, I. N., Shcherbakov, R. A., Shalygo, N. V. (2009): Effect of low above zero temperature on the content of low molecular antioxidants and activities of antioxidant enzymes in green barley leaves. - Russ J Plant Physiol 56(2): 175-180.

[48] Richmond, K. E., Sussman, M. (2003): Got silicon? The non-essential beneficial plant nutrient. - Curr Opin Plant Biol 6: 268-272.

[49] Royal Botanic Gardens (2014): Royal Botanic Gardens and Domain Trust Annual Report. - Royal Botanic Gardens, Sydney.

[50] Sairam, R. K., Rao, K. V., Srivastava, G. C. (2002): Differential response of wheat genotypes to long-term salinity stress in relation to oxidative stress, antioxidant activity and osmolyte concentration. - Plant Sci 163: 1037-1046.

[51] Savant, N. K., Snyder, G. H., Datnoff, L. E. (1997): Silicon management and sustainable rice production. - Adv Agron 58: 151-199.

[52] Seckin, B., Sekmen, A. H., Türkan, İ. (2009): An enhancing effect of exogenous mannitol on the antioxidant enzyme activities in roots of wheat under salt stress. - J Plant Growth Regul 28: 12-20.

[53] Shelton, R. M. (1991): Aloe vera: its chemical and therapeutic properties. - Int J Dermatal 30: 679-83.

[54] Sivanesan, I., Park, W. (2014): The role of silicon in plant tissue culture. - Front. Plant Sci 5: 571.

[55] Soylemezoglu, G., Demir, K., Inal, A., Gunes, A. (2009): Effect of silicon on antioxidant and stomata response of two grapevine (Vitis vinifera L.) rootstocks grown in boron toxic, saline and boron toxic-saline soil. - Sci Hortic Amst 123: 240-246.

[56] Talebi, M. (2013): Bank Keshavarzi's experience in compensating for losses suffered by Iranian farmers as a result of natural disasters. - 4th World Congress on Agricultural and Rural Finance, 26-28 September 2013, Paris.

[57] Tuna, A. L., Kaya, C., Higgs, D., Murillo-Amador, B., Aydemir, S., Girgin, A. R (2008): Silicon improves salinity tolerance in wheat plants. - Environ Exp Bot 62: 10-16.

[58] Van Bockhaven, J., De Vleesschauwer, D., Höfte, M. (2013): towards establishing broadspectrum disease resistance in plants: silicon leads the way. - J Exp Bot 64: 1281-1293.

[59] Waller, G. R., Mangiafico, S., Ritchey, C. R. (1978): A chemical investigation of Aloe barbadensis. - Proceedings of the Oklahoma Academy of Science 58: 69-76.

[60] Yin, L. N., Wang, S. W., Li, J. Y., Tanaka, K., Oka, M. (2013): Application of silicon improves salt tolerance through ameliorating osmotic and ionic stresses in the seedling of Sorghum bicolor. - Acta Physiol Plant35(11): 3099-3107.

[61] Zhang, F., Liang, Y. C., He, W. L., Zhao, X., Zhang, L. X. (2004): Effects of salinity on growth and compatible solutes of callus induced from Populus euphratica. - In Vitro Cell Dev Pl 40: 491-494.

[62] Zhu, J., Liang, Y. C., Ding, Y. F., Li, Z. J. (2006): Effect of silicon on photosynthesis and its related physiological parameters in two winter wheat cultivars under cold stress. Science Agriculture Sinica 39: 1780-1788.

[63] Zhu, X., Song, F., Xu, H (2010): Influence of arbuscular mycorrhiza on lipid peroxidation and antioxidant enzyme activity of maize plants under temperature stress. - Mycorrhiza 20: 325-332.

[64] Zou, W., Chen, Y., Lu, C. (2007): Differences in biochemical responses to cold stress in two contrasting varieties of rape seed (Brassica napus L.). - For Stud China 9(2): 142146. 